\title{
CRIMINOLOGICAL CHARACTERISTIC OF CRIMES IN THE SPHERE OF REAL ESTATE IN UKRAINE
}

\section{Dykyi O. V.}

\section{INTRODUCTION}

The process of formation and development of the residential real estate market in Ukraine takes place under difficult conditions of multidimensional legal, economic and political reforms, which, as a rule, does not contribute to the overall stability of social relations, including in the housing market. The imperfection and imbalance of the current legislation, the lack of a system and coordination in the work of state bodies, inexperience of the participants in the legal relations are factors contributing to the rapid criminalization of the sphere of housing circulation in Ukraine. Instead of a legal, systemic, civilized housing market, there was a phenomenon that could be characterized as a "turnover of residential real estate" with signs of criminal activity.

A significant number of single crimes and systematic criminal activity have created a separate type of crime in the field of turnover of residential real estate. Particular attention deserves a tendency towards the formation and increase of the number of organized groups and criminal organizations operating in the field of illicit trafficking in residential real estate, indicating the transition of crime from the plane of the simple group into a systematic organized form. Such qualitative changes occur in the process of organizing targeted criminal activity, which consists in the systematic commission of criminal encroachment on objects of residential real estate in order to receive short-term extra profits. Another factor of such an organizational change in its structure is the steady tendency for expansion, that is, the inclusion of new participants with special knowledge, hold positions in government bodies. The subjects of such crimes are often the workers of realtor companies and private realtors. Often, accomplices are officials of state authorities, notaries. The criminal activity begins to gain signs of entrepreneurial activity, which exists along with legal and goes to a qualitatively new level of danger to society and the economy as a whole. 
In fact, in this area there is a "criminal business". Specifies the theoretical and practical significance of the research.

\section{Criminal System in the Sphere of Housing Properties and Their Classification}

An important task for our study is the study of crime in the field of turnover of residential real estate from the standpoint of system analysis. This is a prerequisite for an understanding of this type of crime not as a statistical number of individual crimes, but as a certain integral system of delinquent acts of conduct that manifests itself in the area of residential real estate.

The question of crime, as a certain system of crimes, was and remains controversial in the scientific literature. However, most authors agree that crime is not a mere set of crimes ${ }^{1}$. Opponents of the recognition of crime as a system believe that there is no sufficient reason to recognize the crime of the system. In their opinion, crime is not devoid of elements of spontaneity, and the connection between crimes is largely absent, the individual elements of crime are not interrelated links of a holistic system. The very crime in society is preserved, not because of self-development, which is inherent in the systems, but because of the action external to her circumstances - the causes and conditions arising from the specific historical features of society's life. At the same time, they admit that crime has certain characteristics that are characteristic of the system. According to scientists, it should not be denied statistical stability, repeatability of crime. This is due to the fact that acts of criminal behavior are generated by similar determinants. Long-term preservation of these reasons leads to the preservation of the type of distribution of statistical indicators characterizing crime. Scientists argue: this is not enough to recognize

${ }^{1}$ Аванесов Г. А. Теория и методология криминологического прогнозирования. Москва : Юрид. лит., 1972. 334 с.; Волошина Л. А. О системном подходе к изучению сущности преступности. Вопросы борьбы с преступностью. 1972. Вып. 15. С. 15.; Даньшин И.Н. Общетеоретические проблемы криминологии : монография. Харьков : Прапор, 2005. 224 с.; Дрьомін В. М. Злочинність як соціальна практика: інституціональна теорія криміналізації суспільства : монографія. Одеса: Юрид. л-ра, 2009. 616 с.; Дрёмин В. Н. Преступность как обьект системного анализа. Актуальні проблеми держави і права. 2000. № 7. С. 242-255.; Кудрявцев В. Н. Причины правонарушений: монографія. Москва: Наука, 1976. 285 с.; Панов М. Об'єкт і система злочинів у сфері господарської діяльності. Юридична Україна. 2010. № 5. C. 13-19. 
crime as a holistic system, but it is quite enough to seriously consider the issue of predicting crime. Also, researchers believe that although the crime figure is spontaneous, it is not a mechanical sum of certain criminal acts, but their organic set, the constituent elements of which are interconnected and interdependent. Between all signs of crime as a social phenomenon, there is a dialectical unity.

We adhere to the point of view of researchers who characterize crime as a system. In addition, crime in residential real estate turnover should also be considered as a system that can be explained by the following provisions ${ }^{2}$.

In interaction with the environment crime in the field of turnover of residential real estate is considered as a subsystem of a wider system (crime). The latter is a subsystem of the highest with respect to it, a wider system - the social system of society. The crime in the sphere of residential real estate circulation has the integrity of the interconnected elements that make up it. In order to recognize crime in the field of residential property as a system, it is worth paying attention to such a sign as an emergence. The axiom of the emergence means that the whole always has special properties that are absent from its subsystems and is not equal to the sum of elements not united by system-forming connections. When creating a system-wide integrity, the resulting integration is subject to another (albeit possibly, and similar) laws of formation, functioning and evolution. The term "emergence" refers to the presence of all properties that are not reduced to the sum of the properties of the components and the connections between them ${ }^{3}$.

Another feature that characterizes crime in the sphere of residential real estate as a system is its property of self-reproduction at the expense of preservation, adaptation to new conditions, influence on society through direct involvement in the criminal activities of new individuals. Criminality is always adapted to the environment, self-evolving and selfdeterministic as a self-governing system.

2 Кудрявцев В. Н. Курс советской криминологии: Предмет. Методология. Преступнось и её причины. Преступник. Москва: Юрид. лит-ра. С. 148-149; Шипунова Т. В. Подходы к обьяснению преступности: противостояние или взаимодополнение (взгляд социолога). Социологические иследования. 2006. № 1. С. 91.

${ }^{3}$ Сутурин М. А. К вопросу о преступности как системе. Вестник южноуральского государственного университета. Серия: Право. 2006. № 13. С. 170. URL: http://cyberleninka.ru/article/n/k-voprosu-o-prestupnosti-kak-sisteme (дата звернення: 05.07.2017) 
To substantiate the systemic and structural nature of crime, it is necessary not only to highlight individual substructures (elements), but also to identify the objective connections between them. An objective relation is defined as a relation between objects and their properties, which (by virtue of their interaction) leads to the fact that the change of one is accompanied by the change of others. For example, encroachment on objects of residential real estate of citizens in most cases was accompanied by committing other additional crimes, which in their aggregate create separate types of crime (forcible, economic crime, etc.). The specified additional crimes are committed, as a rule, in order to facilitate possession of the right of ownership of objects of residential real estate or to conceal the consequences of criminal activity.

All elements of crime in the sphere of circulation of residential real estate as a system (crime, types of crime) are interrelated, that is, crime has its own structure. Speaking about the crime in the sphere of residential real estate as a system, it is necessary to pay attention to the fact that the allocation of structural components of crime is possible for various reasons. Conducting the specified classification of crimes in this area is one of the main conditions for a substantive and detailed study of crime in the field of turnover of residential real estate.

Questions related to the conduct of classifications, are one of the sharpest methodological problems of modern legal science, as emphasized by researchers ${ }^{4}$. In addition, the creation of new classifications faces numerous and varied difficulties, overcoming which is a difficult and time-consuming process due to the lack of defined criteria.

We consider it reasonable that any classification should meet the requirements, namely: the division is carried out only on one basis, it

4 Кабанов П. А. Криминологическая классификация жертв политических преступлений в современной российской криминальной политической виктимологии. Юридическое образование и наука. 2007. № 4. С. 24-27; Устинова Т. Д Классификация преступлений в сфере экономической деятельности. Закон и право. 2003. № 3. С. 54-58; Николайченко В. В. Криминалистическая классификация пре ступлений. Вестник Саратовской государственной академии права. 2006. № 6. С. 125-127; Коробов П. Классификация преступлений по уровню их опасности. Российская юстиция. 2004. № 1. С. 47-49; Гревцева А. Ю. Классификация преступлений в современном уголовном праве. Закон и право. 2009. № 9. С. 51-54; Богданчиков С. В. Уголовно-правовая классификация преступлений против собственности. Закон и право. 2008. № 6. С. 36-38. 
must be proportional or exhaustive, that is, the number of elements of division must correspond to the volume of the concept that is divided, the elements of division should mutually exclude each other, the division must be continuous 5 .

As O.G. Kalman, in the first textbooks on criminology, the classification of crimes coincided with the classification of them in a special part of criminal law. The further development of criminological science has shown the lack of such an approach to solving criminological problems. Borrowed from the criminal law of the classification of crimes, can not satisfy the criminology, which considers the crime in the socio-legal aspect. Indeed, the classification of crimes by the degree of their social danger, the object of encroachments, although containing significant criminological information, but do not allow deeper to know the causes of the commission of crimes, the motivation of behavior, the identity of the offender, the situation of the crime, etc. At the same time, for criminology is very important situationpersonal factor, without which it is impossible to analyze the mechanism of unlawful conduct, the establishment of circumstances conducive to crime, etc. Thus, for criminology, there are other criteria (grounds) for the classification ${ }^{6}$.

In the scientific literature, scientists have proposed a significant number of both criminological and criminal-legal classifications. It is worth noting that the classifications developed in the science of criminal law are of interest to criminology, but they may not always satisfy the needs of criminological theory and practice, since they can not fully cover all peculiarities of committing crimes that are relevant to their prevention. The criminological classification of crimes involves taking into account certain criteria (attributes), depending on the purposes of classification.

A.F. Zelinsky argued that the criterion of criminological classification may be the nature of a socially dangerous act, which in turn is determined by the orientation of one or another object, the

${ }^{5}$ Маршакова Н. Н. Классификация в российском уголовном законодательстве: Теоретико-прикладной анализ : автореф. дис. на соиск. учен. степ. канд. юрид. наук : 12.00.08. Нижний Новгород, 2006. 30 с.

${ }^{6}$ Криминология: Учебник / под ред. В. Н. Кудрявцева, В. Е. Эминова. Москва: Юристь, 1997. С. 208. 
method of commission, the motivation, the form of guilt and some features of the subject ${ }^{7}$.

However, despite the diversity of criminological classifications, there is still no single classification of crimes committed in the field of turnover of residential real estate in criminology, and the development of such a classification is quite problematic, given its heterogeneity and multi-dimensional aspect.

We will analyze the experience of foreign authors who have researched research on this subject. V.M. Antonov divides the whole set of crimes in the sphere of turnover of residential real estate into two large groups: crimes against buyers and crimes against sellers (owners) ${ }^{8}$. It should be noted that such a classification is incomplete, since in the sphere of turnover of residential real estate there are often crimes committed not against the victim's property, but, for example, against the authority of state authorities, local authorities, which directly concern the forging of documents, seals, stamps and the forms provided for in Article 357 of the Criminal Code of Ukraine, or forcing the execution or non-fulfillment of civil-law obligations stipulated by Article 355 of the Criminal Code of Ukraine, etc.

S.Yu. Arzumanov, conducting a classification of crimes in the field of turnover of residential real estate, identifies several criteria for such a division. Depending on the organizational and economic spheres of the market, the author shares the crimes in the sphere of sale and purchase, mines, rent and rental of housing (fraud and extortion); crimes in the sphere of activity of building and realtor organizations (evasion of payment of taxes and duties (mandatory payments) included in the taxation system) $)^{9}$.

Depending on the purpose of the commission, the author highlights: crimes directly aimed at achieving a criminal result; crimes aimed at facilitating the commission of the above crimes; crimes aimed at concealing the consequences of the above-mentioned crimes. The stated

7 Зелинский А. Ф. О криминологической классификации пре ступлений. Проблемы социалистической законности на современном этапе коммунистического строительства. 1978. С. 210-212.

${ }^{8}$ Антонов В. Н. Преступные посягательства на рынок жилья : автореф. дис. на соиск. учен. степ. канд. юрид. наук : 12.00.08. Владивосток, 1998. 15 с.

9 Арзуманов С. Ю. Криминологическая характеристика и предупреждение преступлений, совершаемых на рынке жилой недвижимости: автореф. дис. на соиск. учен. степ. канд. юрид. наук спец.: 12.00.08. Москва, 2006. 20 с. 
criterion proposed by the author is reasonable, but it is not possible to fully agree with the elements that the scientist points out. Thus, crimes against human life and health in this classification can be regarded as crimes aimed at facilitating the commission of a crime aimed at achieving a criminal result, and in crimes aimed at concealing the consequences.

Investigation of sentences in criminal cases (criminal proceedings) allows us to conclude that in the area of turnover of residential real estate there are crimes that cover a wide range of sections and articles of the Criminal Code of Ukraine.

Crime in the sphere of residential real estate turnover, as a certain system, is divided into two large subsystems: crime in the sphere of rental of housing and crime in respect of encroachment on ownership of residential property in the case of other types of civil law agreements (for example, purchase and sale, mines, donations, etc.). Of course, like any other, the specified division is conditional, but it will continue to be necessary in investigating the personal qualities of the offender and victim, as well as during the development of measures to prevent the crime of the specified species, taking into account the specificities of the factors generating and facilitating the commission of crimes and the subject of attacks that have certain differences in these types of crime.

Depending on the purpose of committing crimes in the sphere of turnover of residential real estate, it is possible to distinguish between two groups: the main ones, which are aimed at realization of the criminal intention, that is, possession of funds, residential real estate, or the acquisition of the right to the specified property (this group directly includes fraud and extortion); related crimes related to the commission of the main crime and are usually aimed at facilitating his commission or aimed at concealing the consequences of criminal acts (falsification of documents, bodily harm, corruption offenses, etc.).

Depending on the subject of encroachment crimes in the field of turnover of residential real estate can be divided into the following groups: aimed at taking possession of the victims and aimed at taking ownership of the object of residential real estate. 


\section{Quantitative and Qualitative Indicators of Crime in the Human Resource Development of Ukraine}

The criminological characteristic of any kind of crime involves the study of its quantitative and qualitative indicators, which in the criminological science is taken to classify level, dynamics, geography, structure, etc. Investigation of indicators of crime in the field of turnover of residential real estate will allow to trace the scale of the spread of this type of crime in Ukraine, as well as to determine its place in the structure of crime in general.

Immediately before studying the indicators of the specified type of crime it is necessary to pay attention to the reliability of the received data, which is connected with several factors. Thus, in the statistical reporting of the Ministry of Internal Affairs of Ukraine there is no information about fraud or extortion committed in the field of turnover of residential real estate, therefore we will use the data obtained during our own research, as well as received by other scientists who have been working in this area. Another factor hindering the assessment of the real level of crime in this area is the high level of latency of these crimes. Data used by scientists to use it will also be used for its definition.

Criminological characteristics of crime in the field of turnover of residential real estate will be carried out on the basis of 240 investigated sentences in criminal cases (criminal proceedings) in the course of committing fraud or extortion of property rights to residential real estate, or proceeds from their sale, or in advance payments, etc., which were approved in the period from 2004 to 2015 on the territory of Ukraine. The above materials are freely available on the official website of the "United State Register of Judicial Decisions". During the study of 240 sentences in criminal cases (criminal proceedings), 670 episodes of crimes were detected and 433 people were convicted. Taking into account that the statistics of the Ministry of Internal Affairs of Ukraine are of a limited nature, contain only general indicators of fraud and extortion and, as a result, do not provide detailed information concerning the criminological characteristics of these crimes, we will continue to use the data obtained on the basis of our research ${ }^{10}$.

10 Дикий О.В. Кримінологічні засади вивчення і попередження злочинів у сфері обороту житлової нерухомості в Україні: автореф. дис. канд. юрид. наук: 12.00.08. Одеса, 2015. С. 8. 
The first indicator to be investigated is the level of crime. Using information contained in sentences in criminal cases (criminal proceedings), it can be argued that since 2004, the level of crime in the field of turnover of residential real estate has steadily increased. It was found that 34 crimes were committed in 2004, in 2005 - 46, in $2006-$ 51 , in $2007-96$, in $2008-58$, in $2009-45$, in $2010-59$, in $2011-94$, in $2012-53$, in $2013-53$, in $2014-81$. In addition, a significant number of crimes that were not detected, that is, remained latent, should be taken into account. In total, this figure for fraud is $49 \%$. It can be assumed that in the sphere of turnover of residential real estate the indicator is much higher, but such information can not be confirmed on the basis of empirical data that was investigated.

It should be noted that the Unified State Register of Judgments (hereinafter referred to as the USSR) was actually created in 2006, but today there are some problems with filling the very Single State Register of court decisions. Also, it should be noted that the data received in 2013 are incomplete because some cases (criminal proceedings) have not yet been convicted. Therefore, data for 2004-2006, 2013-2014 are not, despite this, studies show that crime in the field of turnover of residential real estate is beginning to gain more mass character.

Studies conducted by us show a steady tendency to increase the number of committed crimes. However, the sharp jump in the level of crime in 2007 and 2011 and the decrease in other years, in our opinion, does not indicate a critical criminal situation in the field of turnover of residential real estate and the effective activity of state structures in preventing this type of crime, but the imperfection and unsystematic conduct of previous years of the USSR. Given the important social and legal reforms that began in Ukraine in 2014, as well as the significant decline in the economy and material provision of the population, it is worth assuming that the level of crime in the field of turnover of residential real estate in the future will also have a tendency to increase.

It should also be borne in mind that in the territory of Ukraine, temporarily occupied as a result of armed aggression of the Russian Federation and on the territory of the operation of the combined forces, there is virtually no statistical record of offenses. That is, the actual level of crime significantly exceeds the registered.

Also, it should be noted that starting from 2013, in the statistical information of the General Prosecutor's Office of Ukraine "On 
Registered Criminal Offenses and the Results of Their Pre-trial Investigation," an additional Count of Fraud Schedule "related to the Acquisition of Property" appeared. Thus, in 2013 there were 1335 registered, and in 2014- 1024 criminal offenses related to ownership of real estate. Of these, in 2013, in 56 cases, individuals were notified of suspicion and in 41 cases, criminal offenses were sent to the court with a criminal act, and in 2014 - 71 and 46 respectively. However, in our work, we can not fully utilize these indicators, because in the column "related to real estate ownership" also other types of real estate, such as land, etc. are taken into account.

It should be noted that our research did not find confirmation of the hypothesis about the direct link between the dynamics of crime and purchasing activity in the field of turnover of residential real estate. This is confirmed by the fact that the volatility of the number of transactions in the field of turnover of residential real estate did not affect the number of crimes committed. Thus, according to the Ministry of Justice of Ukraine, in 2012, about 266,000 agreements with apartments and residential buildings were registered, in 2011 - 254030, in $2010-$ 218120 , in $2010-217029$, in $2008-158431$, in $2007-126744^{11}$.

It should be noted that in the scientific literature there was no research on determining the level of latency of crime in the field of turnover of residential real estate, and given the insignificant amount of empirical material, it is not considered possible to conduct a representative survey for today. To determine the level of crime latency in the field of turnover of residential real estate, we will use the results of research by other scientists, obtained on the basis of study of the latency of crime in general. Thus, B.Golovkin conducted a study of the level of latent mercenary-violent crime in Ukraine in Kharkiv and Cherkasy regions in 2008. In total, 1104 people were interviewed. Based on the data obtained during the survey, the author came to the conclusion that the level of latency of selfish-violent crimes is at $54 \%$ of the total number of crimes committed ${ }^{12}$.

11 Другий рік поспіль ринок нерухомості в Україні демонструє поступове зростання. веб-сайт. URL: http://www.kmu.gov.ua/control/uk/publish/article?art_id= 246069296\& cat_id=244276429 (дата звернення: 05.07.2017).

12 Головкін Б. Латентний вимір корисливої насильницької злочинності в Україні. Юридична Україна. 2009. № 6. С. 113. 
V.S. Batyrhareyeva on the basis of the anonymous questionnaire, 461 persons from the number of convicted recidivists found that $74.6 \%$ of them had committed other crimes before the last conviction, which were unknown to law enforcement authorities, in addition, 82.9\% of them said that they had committed the offense repeatedly. That is, the actual size of recurrent crime is at least twice as high as the registered one ${ }^{13}$.

Using these studies of scholars and considering them reliable, it can be argued that the level of crime in the area of turnover of residential real estate is twice that of registered indicators. To fulfill the goals of our study, we also consider it necessary to turn to the mechanism of the formation of the latent part of crime in the field of turnover of residential real estate proposed by V.S. Batrygareyeva ${ }^{14}$.

Particular attention deserves the last two types of artificial latency, as in the area of turnover of residential real estate criminals disguise illegal activities under civil law operations. In addition, law enforcement agencies can easily err on the basis of poor legal training and lack of professional experience in determining the nature of social relations that have arisen between individuals and to provide such relations only with civil status, which will not allow full protection of rights in the future and the interests of the victim.

The next crime indicator is the structure, the essence of which is to describe the correlation between groups and types of crimes. It always reflects the relationship between parts of the whole. In this section, we will not provide a detailed description of the elements allocated on the basis of socio-demographic and criminal-law criteria, as this is not the subject of the study. Here we turn attention only to the most urgent problems.

The whole set of crimes in the area of residential real estate can be divided into two large groups: crimes in the field of lease of residential property and crimes in the case of other civil-law contracts. These contracts include, in particular, the sale and purchase of residential property, mines, the making of wills, etc.

13 Батиргареєва В.С. Кримінологічний аналіз латентної рецидивної злочинності. Актуальные проблемь криминологии и криминальной психологии / под ред.: М. Ф. Орзиха, В. Н. Дремина. Одесса, 2007. С. 107.

14 Лунеев В. В. Преступность ХХ века: мировые, региональные и российские тенденции. Москва : Волтерс Клувер, 2005. С. 110. 
It was established that out of 240 sentences 82 were adopted in respect of persons who committed crimes in the field of lease of residential real estate, 158 in relation to persons when concluding other civil-law contracts, of which 7 were made against extortionists. That is, the absolute majority of crimes is committed by fraud.

We will analyze the crime in these areas, depending on the severity of the crimes provided for in Article 12 of the Criminal Code of Ukraine. Thus, the investigation of sentences showed that in the area of lease of residential real estate persons committed exclusively fraud for the capture of the victims, in addition, the prevalence of the commission of crimes of average gravity - 204, the small gravity was recorded 63 cases, 1 case of a grave crime (a total of 268). This situation can be explained by the small amount of money offended by the perpetrators and the relative ease of committing such attacks, which does not require unification into stable groups (organized crime groups, criminal organizations) to achieve intent.

In contrast to the sphere of rental of housing, during the conclusion of other treaties of a civil nature, the number of especially serious and grave crimes prevails. Yes, we have registered particularly serious crimes -213 , serious crimes -109 , medium gravity -64 , crimes of minor gravity $-16^{15}$.

This is due to the commission of crimes in particularly large numbers and organized groups. However, despite the special danger of such crimes, it is worth noting the rather humane activity of the justice system, which will be discussed in the next section.

Particular attention deserves the group nature of crime in the area of turnover of residential real estate, which has a steady tendency to improve criminal qualifications, internal organization, professionalism, technical equipment, which greatly complicates the implementation of effective activities to prevent the crimes committed by such groups. Investigation of the adopted sentences showed that in 141 cases (out of 240 sentences) the crimes were committed alone, in 78 cases - by the group under the previous convocation, in 3 cases by a group without

15 Дикий О. В. Кримінологічна характеристика способів вчинення шахрайств в сфері обороту житлової нерухомості. Часопис Академії адвокатури України. 2014. T. 7. № 2. С. 36. Режим доступу: http://nbuv.gov.ua/j-pdf/Chaau_2014_7_2_5.pdf (дата звернення: 05.07.2017). 
prior conspiracy, in 17 - by an organized group and in one case by a criminal organization.

In general, 341 episodes of crimes committed in the field of turnover of residential real estate were established in organized forms. In addition, the level of latent recidivism is $80 \%$ of the total number of crimes committed.

Detailed analysis of the group nature of crime in the area of residential real estate. So, in contrast to fraud, during extortion, crimes were committed only with complicity. We recorded 4 cases of organized crime by organized groups (16 episodes in total), 4 cases of crimes committed by a group on the basis of a preliminary conspiracy (only 14 episodes) and 1 case of crime by a criminal organization (total 7 episodes). Based on these data, we can say that about 37 victims lost their housing.

To fully investigate the group nature of the fraud, we consider it appropriate to divide it into two groups depending on the sphere of civillaw relations: during the lease of residential real estate objects and the implementation of other civil-law contracts. In the field of the conclusion of contracts of civil law, in addition to lease, in 84 cases, the crimes committed alone, in 56 cases, the group by preliminary agreement, in 1 case, the group without a preliminary conspiracy, 16 - organized by the group and in one case, a criminal organization. According to our research, in the group 34 cases consisted of 2 persons, in 13 cases -3 persons, in 16 cases -4 persons and in 10 cases - more than 5 people.

When renting a home significantly exceeds the number of crimes committed alone, without complicity. This can be explained by the simplicity of an agreement, usually a small cost of rental housing and legal illiteracy of victims. The data are as follows: without complicity, 57, according to the previous conspiracy by a group of people (92\% 2 persons) -22 . The absence of crimes committed by organized groups, in our opinion, is associated with low profitability of such activities for them ${ }^{16}$.

It should be noted that although the majority of crimes are committed by groups according to the above-mentioned data, they are concerned

16 Дикий О. В. Кримінологічна характеристика особистості злочинця в сфері обороту житлової нерухомості. Актуальні проблеми держави і права : зб. наук. пр. 2013. Вип. 70. С. 350. 
about the increase in the number of identified organized groups and criminal organizations, indicating the transition of crime from the plane of simple group crime into its organized form. Such a qualitative transition occurs in the process of criminal activity, consisting in the systematic commission of the same type of criminal encroachment on objects of residential real estate for short-term extra profits.

Another factor of such an organizational change in its structure is the persistent tendency for expansion, that is, the inclusion of new participants with specialist knowledge, sometimes occupy positions in state bodies. This is due to the improvement of the mechanisms of committing crimes to accelerate the achievement of the criminal result, as well as to conceal the signs of the activity of such a group. It is worthwhile to note that criminal activity is a system of criminal acts envisaged by the criminal law and closely related to other pre-criminal and post-criminal acts that are psychologically determined by a general motive, the realization of which is planned by the subject by setting and achieving separate, intermediate goals. According to the scientist, criminal activity is carried out not in isolation from other, legal activities. But in some cases criminal activity seems to be intertwined with labor, namely, in management activity ${ }^{17}$. The stated statement of the author is clearly traceable during the investigation of the criminal activity of persons in the area of housing turnover. After all, the actors of such crimes are workers of real estate companies, private realtors, often accomplices are officials of state authorities, notaries. The criminal activity begins to gain signs of entrepreneurial activity, which exists along with legal and goes to a qualitatively new level of danger to society and the economy as a whole, in fact, in this area there is a "criminal business". The most characteristic is the activity of organized crime in this area, which defines itself as a special kind of criminal practice, which eventually increasingly shows signs of a social institution. In addition, the degree of institutionalization of this type of crime is largely determined by its fundamental properties: the organization and systematic nature of criminal forms of behavior ${ }^{18}$.

17 Зелинский А. Ф. Криминальная психология : монография. Киев : Юринком Интер, 1999. С. 96.

18 Дрьомін В. М. Злочинність як соціальна практика: інституціональна теорія криміналізації суспільства : монографія. Одеса: Юрид. л-ра, 2009. С. 428. 
Based on the data obtained during the investigation of sentences, it can be argued that crime in the conclusion of various types of contracts of a civil law nature (except for rent) does not apply to seasonal crime. Thus, in the autumn there were 117 cases of committing crimes, 109 in the winter, 109 in the spring and 121 in the summer.

However, another situation is observed in the area of rental housing. In 88 cases, crimes committed in the fall, 72 in summer, 64 in winter and 64 in spring. It is worth paying attention that crimes in this area are committed during the long-term lease (from 1 month). The increase in the level of crime during the rental of housing in the autumn can be explained by the increase in demand and such objects of residential real estate. It should be noted that the most common group of tenants are young people who, by their social status, are students or persons not working at their place of residence, as well as tourists, they do not have sufficient skills and experience to protect themselves from criminals.

Particular attention for the criminological characteristics of any type of crime deserves the study of the identity of criminals. Therefore, in the next section, it will be exactly this.

\section{CONCLUSIONS}

On the basis of the study, it was substantiated that a large number of single crimes and systemic criminal activity form a separate type of crime that affects the various spheres of society and other forms of crime that it generates. Crime in the field of turnover of residential real estate is a system of crimes, which is divided into two subsystems: crime in the field of rental housing and crime in case of encroachment on ownership of residential property in the conclusion of other types of civil law (for example, purchase and sale, mines, donations, etc.).

Depending on the purpose of committing crimes in the sphere of turnover of residential real estate, it is possible to distinguish between two groups: the main ones, which are aimed at realization of the criminal intention, that is, possession of funds, residential real estate, or the acquisition of the right to the specified property (this group directly includes fraud and extortion); Related related to the commission of the main crime and are usually aimed at facilitating his commission or aimed at concealing the consequences of criminal acts (forgery of documents, bodily harm, corruption offenses, etc.). 
The dynamics of crime in the field of turnover of residential real estate has a steady tendency to increase the number of committed crimes. The study did not find confirmation of the hypothesis about the direct connection of crime and economic processes occurring in the field of turnover of residential real estate. Attention is drawn to the high level of latency of crime in the field of turnover of residential real estate.

Particular attention deserves the group nature of crime in the field of turnover of residential real estate, which has a steady tendency to improve criminal skills, internal organization, professionalism, technical equipment, which greatly impedes the effective conduct of crime prevention activities committed by such groups.

It was proved that in the sphere of turnover of residential real estate the tendency to increase the recidivism of crimes is changing, which is extremely unfavorable factor for preventive activity of law enforcement bodies in this area. It is established that crimes in the field of turnover of residential real estate in their mechanism of implementation are quite complicated. Because of this, often committed with complicity to facilitate his commission, as well as to accelerate the achievement of a criminal goal.

\section{SUMMARY}

The thesis is a criminological research into crime in the sphere of residential real estate turnover in Ukraine. It is established that a significant number of individual crimes and systematic criminal activity create an independent type of crime. As a certain system, crime in the sphere of residential real estate turnover is divided into two large subsystems: crime in the sphere of rent of residential real estate and crime related to infringement on the ownership right on residential real estate objects in the process of conclusion of other types of civil legal agreements (for example, buying-selling, barter, deed of gift etc.). The analysis of empirical data has revealed that the dynamics of criminality in the sphere of residential real estate turnover has a stable tendency of growth in the number of committed crimes. The thesis highlights the high level of latent criminality in the sphere of residential real estate turnover and group character of criminality in the sphere of residential real estate turnover, which has a constant tendency of improvement of level of criminal proficiency, internal organization, professionalism, technical equipment, etc.; and the tendencies of recidivism growth. 


\section{REFERENCES}

1. Аванесов Г. А. Теория и методология криминологического прогнозирования. Москва : Юрид. лит., 1972. 334 с.

2. Антонов В. Н. Преступные посягательства на рынок жилья : автореф. дис. на соиск. учен. степ. канд. юрид. наук : 12.00.08. Владивосток, 1998. 15 с.

3. Арзуманов С. Ю. Криминологическая характеристика и предупреждение преступлений, совершаемых на рынке жилой недвижимости: автореф. дис. на соиск. учен. степ. канд. юрид. наук спец.: 12.00.08. Москва, 2006. 20 с.

4. Батиргареєва В. С. Кримінологічний аналіз латентної рецидивної злочинності. Актуальные проблемы криминологии и криминальной психологии / под ред.: Орзиха М. Ф., Дремина В. Н. Одесса, 2007. С. 106-113.

5. Богданчиков С. В. Уголовно-правовая классификация преступлений против собственности. Закон и право. 2008. № 6. С. 36-38.

6. Волошина Л. А. О системном подходе к изучению сущности преступности. Вопросы борьбы с преступностью. 1972. Вып. 15. С. 11-23.

7. Головкін Б. Латентний вимір корисливої насильницької злочинності в Україні. Юридична Україна. 2009. № 6. С. 110-116.

8. Гревцева А. Ю. Классификация преступлений в современном уголовном праве. Закон и право. 2009. № 9. С. 51-54.

9. Даньшин И. Н. Общетеоретические проблемы криминологии : монография. Харьков : Прапор, 2005. 224 с.

10. Дикий О. В. Кримінологічні засади вивчення i попередження злочинів у сфері обороту житлової нерухомості в Україні: автореф. дис. канд. юрид. наук: 12.00.08. Одеса, 2015. 20 с.

11. Дикий О. В. Кримінологічна характеристика способів вчинення шахрайств в сфері обороту житлової нерухомості. Часопис Академії адвокатури України. 2014. Т. 7. № 2. С. 33-40. Режим доступу: http://nbuv.gov.ua/j-pdf/Chaau_2014_7_2_5.pdf (дата звернення: 05.07.2017).

12. Дикий О. В. Кримінологічна характеристика особистості злочинця в сфері обороту житлової нерухомості. Актуальні проблеми держави і права : зб. наук. пр. 2013. Вип. 70. С. 346-355.

13. Дрёмин В. Н. Преступность как обьект системного анализа. Актуальні проблеми держави і права. 2000. № 7. С. 242-255. 
14. Другий рік поспіль ринок нерухомості в Україні демонструє поступове зростання. веб-сайт. URL: http://www.kmu.gov.ua/ control/uk/publish/article?art_id=246069296\&cat_id=244276429 (дата звернення: 05.07.2017).

15. Дрьомін В. М. Злочинність як соціальна практика: інституціональна теорія криміналізації суспільства : монографія. Одеса: Юрид. л-ра, 2009. 616 с.

16. Зелинский А. Ф. Криминальная психология : монография. Киев : Юринком Интер, 1999. 240 с.

17. Зелинский А. Ф. О криминологической классификации пре ступлений. Проблемы социалистической законности на современном этапе коммунистического строительства. 1978. С. 210-212.

18. Кабанов П. А. Криминологическая классификация жертв политических преступлений в современной российской криминальной политической виктимологии. Юридическое образование и наука. 2007. № 4. С. 24-27.

19. Кальман О. Г. Злочинність у сфері економіки України: теоретичні та прикладні проблеми попередження: дис... доктора юрид. наук : 12.00 .08 / Національна юридична академія України ім. Я. Мудрого. Харків, 2004. 431 с.

20. Коробов П. Классификация преступлений по уровню их опасности. Российская юстииия. 2004. № 1. С. 47-49.

21. Криминология: Учебник / под ред. Кудрявцева В. Н., В. Е. Эминова. Москва: Юристь, 1997. 512 с.

22. Кудрявцев В. Н. Причины правонарушений: монографія. Москва: Наука, 1976. 285 с.

23. Кудрявцев В. Н. Курс советской криминологии: Предмет. Методология. Преступнось и её причины. Преступник. Москва: Юрид. лит-ра., 416 с.

24. Лунеев В. В. Преступность XX века: мировые, региональные и российские тенденции. Москва : Волтерс Клувер, 2005. $912 \mathrm{c}$.

25. Маршакова Н. Н. Классификация в российском уголовном законодательстве: Теоретико-прикладной анализ : автореф. дис. на соиск. учен. степ. канд. юрид. наук : 12.00.08. Нижний Новгород, 2006. $30 \mathrm{c}$. 
26. Николайченко В. В. Криминалистическая классификация пре ступлений. Вестник Саратовской государственной академии права. 2006. № 6. С. 125-127.

27. Панов М. Об'єкт і система злочинів у сфері господарської діяльності. Юридична Україна. 2010. № 5. С. 13-19.

28. Сутурин М. А. К вопросу о преступности как системе. Вестник южно-уральского государственного университета. Серия: Право. 2006. № 13. С. 170. URL: http://cyberleninka.ru/ article/n/k-voprosu-o-prestupnosti-kak-sisteme (дата звернення: 05.07.2017).

29. Устинова Т. Д Классификация преступлений в сфере экономической деятельности. Закон и право. 2003. №3. С. 54-58.

30. Шипунова Т. В. Подходы к обьяснению преступности: противостояние или взаимодополнение (взгляд социолога). Социологические иследования. 2006. № 1. С. 89-98.

\section{Information about the author: Dykyi O. V.}

Ph.D. in Law, Associate Professor, Acting Dean of Faculty of Cybersecurity and Information Technologies, National University «Odesa Law Academy» 23, Fontanskaya Road, Odesa, 65009, Ukraine 